\title{
Architectural proposal for the rehabilitation and improvement of the houses of the city Yagúl housing unit, Oaxaca
}

\section{Propuesta arquitectónica para la rehabilitación y mejoramiento de las viviendas de la unidad habitacional ciudad Yagúl, Oaxaca}

\author{
HERNÁNDEZ-RODRÍGUEZ, Miguel Adrián†**, GÓMEZ-BARRANCO, Heidy and RODRÍGUEZ- \\ SÁNCHEZ, Luz Cecilia \\ Universidad Autónoma Benito Júarez de Oaxaca (UABJO), Faculty of Architecture "5 de Mayo", Academic Body \\ "Technology and Sustainability". 5 de Mayo No. 111, Historic Center, Oaxaca, Oax. Mexico. 68000.
}

ID $1^{\text {st }}$ Author: Miguel Adrián, Hernández-Rodríguez / ORC ID: 0000-0002-5239-4094

ID $1^{\text {st }}$ Co-author: Heidy, Gómez-Barranco / ORC ID: 0000-0001-7221-1438, Researcher ID Thomson: G-3415-2019, CVU CONACYT ID: 808434

ID $2^{\text {nd }}$ Co-author: Luz Cecilia, Rodríguez-Sánchez / ORC ID: 0000-0002-1546-9050, CVU CONACYT ID: 40518

DOI: $10.35429 / J A D .2021 .14 .5 .27 .36$

Received July 25, 2021; Accepted December 30, 2021

\begin{abstract}
This article presents the results of an investigation carried out in the Yagul city housing unit in the state of Oaxaca, in order to study the deterioration problems that have caused the abandonment of the houses, and in this context, to propose strategies that solve these problems in addition to improving the quality of life of the inhabitants. For this investigation, non-destructive tests were carried out on the houses of the place, such as: Concrete compression resistance test using a digital sclerometer, temperature tests with a thermographic camera and infrared digital thermometer, detection of reinforcements using a portable Pachometer and soil mechanics. . The results obtained have allowed us to know the current state of the houses and based on these data, make an architectural proposal for the rehabilitation and improvement of said houses, generating a bioclimatic environment and comfort for its inhabitants.
\end{abstract}

Rehabilitation, Bioclimatism, Non-destructive testing

\begin{abstract}
Resumen
En este artículo se presentan los resultados de una investigación llevada a cabo en la unidad habitacional de ciudad Yagul en el estado de Oaxaca, con el fin de estudiar los problemas de deterioro que han provocado el abandono de las viviendas, y en este contexto, plantear estrategias que solucionen estos problemas además de mejorar la calidad de vida de los habitantes. Para esta investigación se realizaron pruebas no destructivas a las viviendas del lugar, tales como: Prueba de resistencia a compresión de concreto mediante un esclerómetro digital, pruebas de temperatura con cámara termográfica y termómetro digital infrarrojo, detección de armaduras mediante Pachometro portátil y mecánica de suelos. Los resultados obtenidos han permitido conocer el estado actual en que se encuentran las viviendas y a partir de estos datos hacer una propuesta arquitectónica de rehabilitación y mejoramiento de dichas viviendas generando un ambiente bioclimático y de confort para sus habitantes.
\end{abstract}

Rehabilitación, Bioclimatismo, Pruebas no destructivas

Citation: HERNÁNDEZ-RODRÍGUEZ, Miguel Adrián, GÓMEZ-BARRANCO, Heidy and RODRÍGUEZ-SÁNCHEZ, Luz Cecilia. Architectural proposal for the rehabilitation and improvement of the houses of the city Yagúl housing unit, Oaxaca. Journal Architecture and Design. 2021. 5-14:27-36.

\footnotetext{
* Correspondence to Author (Email: miguel.ahr117@gmail.com)

$\dagger$ Researcher contributing as first author.
} 


\section{Introduction}

In recent years, the discourse of "social housing" has been characterized by real estate voracity, uninhabited housing, vandalized and far from the workplace. Today, the way of building housing in Mexico is based on a nondescript and generic model of serial repetition ${ }^{2}$.

In this article, an architectural proposal was carried out in the housing unit of the Yagul city, Municipality of Tlacolula Oaxaca.

Non-destructive tests were carried out on the houses, as well as a soil mechanic to determine the causes of the problems that afflict the inhabitants.

A sample of 5 dwellings was carried out, which allowed us to analyze the results of the state in which they are located.

The architectural proposal was born with the intention of improving the homes that currently exist, both in the structural aspect and the comfort of the inhabitant, in addition to generating a complex and raising awareness of the environment of the area, proposing several elements that help the user of the houses to learn and live with the nature of the environment, the culture and the social and economic activities directly related to the place through its evolution and history of this complex.

\section{Problem statement}

Currently the subdivision has 2,865 homes, of which approximately $45 \%$ are in a situation of abandonment, after a study carried out it is declared that the homes do not comply with the quality of materials or regulations established in the construction regulations of the state of Oaxaca.

The inhabitants of the few occupied dwellings have manifested the low quality of life, problems in the structure of the dwelling, lack of water, intense heat and distance from the city with respect to their workplace.

\footnotetext{
2 Juan José Kochen (2017) "El ideal del multifamiliar: A 70 años del primer centro urbano moderno" Archdaily ISSN 0719-8914.
}

\section{Justification}

In order to carry out the proposal, it was necessary to know the current state of the subdivision, as well as that of the houses, materials used, construction system, regulations among other data, for this it was determined that non-destructive tests were the most suitable to avoid damaging the structures of the place, these tests gave us the necessary information to identify the origin of the aforementioned problems, and thus be able to make a proposal and intervention that solves the current problems.

\section{Hypothesis}

Analyzing the state of the houses and their structural quality, a proposal can be generated that solves the needs detected and the problems mentioned by the users, as well as the abandonment of the houses, proposing an architectural solution that provides thermal comfort, and improves comfort and quality of life of the inhabitants.

\section{Objectives}

\section{General objective}

Carry out an Architectural proposal of the houses through site analysis of the place through non-destructive tests for the improvement and rehabilitation of the architectural spaces of the houses of the Yagúl Tlacolula city housing unit, Oaxaca

\section{Specific objectives}

- Make a planimetric survey and visual inspection of the houses.

- Perform non-destructive tests on homes to determine their structural and bioclimatic status.

- $\quad$ Perform soil mechanics through open pit (PCA) sampling to find out the type of soil.

- Develop an architectural Proposal based on the results for the improvement of homes and the subdivision in general. 


\section{Analysis of the house}

\section{Mexican Housing Regulations}

The regulations on housing at the government level are: the National Housing Commission (CONAVI), the Institute of the National Housing Fund for Workers (INFONAVIT), the ISSSTE Housing Fund (FOVISSSTE), and the Housing Fund Military (FOVIME).

The national housing law is regulated in article 4. of the Political Constitution of the United Mexican States on housing, which establishes the right of every family to enjoy a decent and decent home. Housing is a universal right of every human being.

In addition to the aforementioned, the following laws and regulations should be taken into account when designing and building the aforementioned housing unit.

- $\quad$ Regulation of subdivisions.

- $\quad$ Regulation of construction and structural safety of Oaxaca.

Within the INFONAVIT Law, in the table "Minimum dimensions of housing according to official provisions and regulations" (INFONAVIT, 2006), the necessary surface for each space in the house, the heights, the circulation and the natural ventilation. The minimum free area per space must correspond to what is established in Table 1. According to the UNE-EN ISO 7730: 2006 standard, the ideal temperature for a house in winter is 21 degrees Celsius.

\begin{tabular}{|c|c|c|}
\hline Living space & $\begin{array}{l}\text { Minimum } \\
\text { area }\end{array}$ & $\begin{array}{l}\text { Minimum } \\
\text { side }\end{array}$ \\
\hline LIVING ROOM & $7.29 \mathrm{~m}^{2}$ & $2.70 \mathrm{~m}$ \\
\hline Dining room & $4.41 \mathrm{~m}^{2}$ & $2.10 \mathrm{~m}$ \\
\hline Recharge & $7.29 \mathrm{~m}^{2}$ & $2.70 \mathrm{~m}$ \\
\hline Bedroom & $3.60 \mathrm{~m}^{2}$ & $2.00 \mathrm{~m}$ \\
\hline \multicolumn{3}{|l|}{ Auxiliary space } \\
\hline Kitchen room & $3.30 \mathrm{~m}^{2}$ & $1.50 \mathrm{~m}$ \\
\hline Bathroom & $2.73 \mathrm{~m}^{2}$ & $1.30 \mathrm{~m}$ \\
\hline 1/2 Rectangular Bath & $1.69 \mathrm{~m}^{2}$ & $1.30 \mathrm{~m}$ \\
\hline $1 / 2$ Long Bath & $1.44 \mathrm{~m}^{2}$ & $0.80 \mathrm{~m}$ \\
\hline Laundry & $2.56 \mathrm{~m}^{2}$ & $1.60 \mathrm{~m}$ \\
\hline Playground & $1.96 \mathrm{~m}^{2}$ & $1.40 \mathrm{~m}$ \\
\hline Patio- Laundry & $2.66 \mathrm{~m}^{2}$ & $1.40 \mathrm{~m}$ \\
\hline \multicolumn{3}{|l|}{ Overlapping } \\
\hline Living-dining room & $12.00 \mathrm{~m}^{2}$ & $2.70 \mathrm{~m}$ \\
\hline $\begin{array}{l}\text { Living room-dining } \\
\text { room-kitchen }\end{array}$ & $14.60 \mathrm{~m}^{2}$ & $2.70 \mathrm{~m}$ \\
\hline
\end{tabular}

Table 1 Minimum dimensions for Living and Auxiliary Spaces (CONAVI)

ISSN 2531-2162

ECORFAN ® All rights reserved.

\section{Materials and methods}

\section{Description of the structure and visual inspection}

The research focuses on a hypotheticaldeductive method, in which the quality of the dwellings and their thermal comfort in relation to the inhabitant are considered, this method is part of the qualitative approach for the analysis of the dwellings.

For this analysis, 5 random homes were selected from the subdivision, these homes were built by the company "Genesis 2000", these have a height of $2.50 \mathrm{~m}$ at the bottom of the slab and consist of 2 bedrooms, a full bathroom and a common kitchen area. and dining room, as well as a service patio, having a total of $40 \mathrm{~m} 2$ of construction.

During the visual inspection, several signs of deterioration in the structure could be observed, as shown in figure 1, which include cracks, humidity, signs of exposure and corrosion of the reinforced steel and the presence of leaching salts in the bed. bottom of the slabs, also subsidence of the ground in some houses.

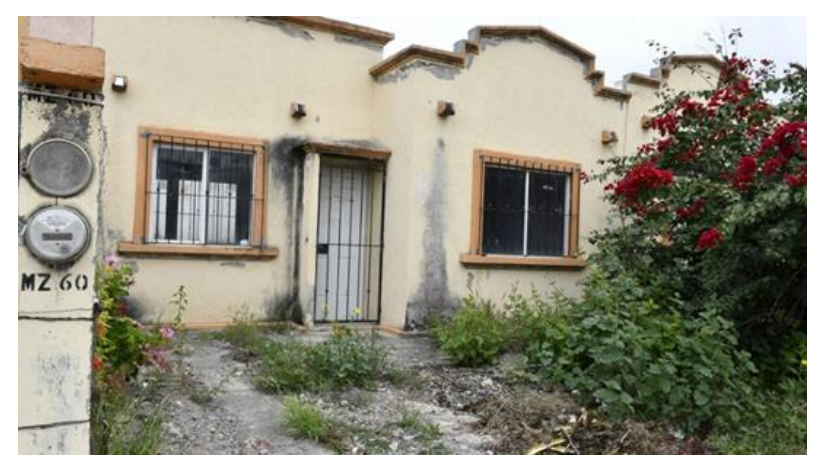

Figure 1 Cracking and moisture in the walls and slabs

\section{Non-destructive tests in concrete}

Derived from the damage observed during the visual inspection process, it was determined to carry out the diagnosis of the state of deterioration of the structure by means of nondestructive tests of concrete, this in order not to damage people's houses.

Tests were carried out on 5 random houses, which will represent the mass of housing that currently exists in the subdivision.

HERNÁNDEZ-RODRÍGUEZ, Miguel Adrián, GÓMEZBARRANCO, Heidy and RODRÍGUEZ-SÁNCHEZ, Luz Cecilia. Architectural proposal for the rehabilitation and improvement of the houses of the city Yagúl housing unit, Oaxaca. Journal Architecture and Design. 2021 
The properties to be evaluated were: the compressive strength ( $\left.f^{\prime} c\right)$ by means of rebound hammer tests (sclerometer), estimation of the quantity and location of the steel reinforcements in the houses with a portable patchometer for reinforcement detection. In addition, temperatures were recorded during the day and at night with an infrared digital thermometer.

In the same way, a thermography of the houses was carried out with a thermographic camera, additionally, a soil mechanics was carried out to know the properties and the bearing capacity of the land (qr) and thus be able to determine if the proposed foundation was the ideal one or the soil should be considered. as a major factor of cracking.

\section{Determination of the $f^{\prime} c$ by rebound hammer}

The rebound hammer (MR) readings were performed in accordance with NMX-C-192, using an ASTM C805 model E5541 digital sclerometer.

The steel readings were marked on the perimeter walls and central walls by making 10 divisions horizontally and 10 vertically with the help of the pachometer, then 10 blows with the hammer were made in the center of the divisions starting from zone 1, up to zone 10 , this was done in order to achieve, as far as possible, run the tests in areas with little congestion of the reinforcing steel, a total of 100 readings were recorded in 10 walls of 5 different houses.

The results of the compression tests obtained by means of sclerometry are shown in Table 2, the average value of the aforementioned readings was considered as the final $\mathrm{f}^{\prime} \mathrm{c}$.

With this we can rectify that the concrete used in the construction of the houses is of very low quality, f'c being the general average of $199.11 \mathrm{~kg} / \mathrm{cm} 2$ which is below what is established in the aforementioned guidelines, which shows the deficiencies in the materials used and the lack of supervision in the housing construction processes.

\begin{tabular}{|c|c|c|c|}
\hline \multicolumn{2}{|c|}{ House 1} & \multicolumn{2}{|c|}{ General summary } \\
\hline Perimeter wall 1 & Wall 2 center & House 1 & \\
\hline 18.82 & 19.22 & average $f^{\prime} c=$ & $19.02 \mathrm{Mpa}$ \\
\hline 18.82 & 19.24 & House 2 & \\
\hline 18.83 & 19.22 & average $f^{\prime} c=$ & $19.41 \mathrm{Mpa}$ \\
\hline 18.82 & 19.22 & House 3 & \\
\hline 18.82 & 19.26 & average $f^{\prime} c=$ & $20.11 \mathrm{Mpa}$ \\
\hline 18.82 & 19.22 & House 4 & \\
\hline 18.82 & 19.22 & average $f^{\prime} \mathrm{c}=$ & $19.55 \mathrm{Mpa}$ \\
\hline 18.82 & 19.22 & House 5 & \\
\hline 18.84 & 19.22 & average $f^{\prime} c=$ & $19.64 \mathrm{Mpa}$ \\
\hline 18.82 & 19.22 & Total f'c average & $19.54 \mathrm{MPa}$ \\
\hline 18.82 & 19.23 & & \\
\hline $\mathrm{Mn}$ & & $1 \mathrm{Mpa}=10.19 \mathrm{~kg}$ & \\
\hline
\end{tabular}

Table 2 Results of sclerometry tests

Estimation of the amount of steel and location of the reinforcements by means of digital pachometer

The scan was carried out using a Profoscope model DA 103 digital pachometer (rod detector).

The readings made will indicate the diameter of the steel used in the construction, as well as the mm of the wall covering.

The detector equipment uses electromagnetic pulse induction technology to detect the rods.

The coils of the probe are periodically charged by current pulses, which generates a magnetic field, eddy currents are produced on the surface of any material that conducts electrical current within the magnetic field, these currents induce a magnetic field in the opposite direction and Depending on the magnitude of the pulse reflected by the rod, the team can estimate the location, orientation, and diameter of the reinforcement.

The resulting change in stress can be used for the detection of embedded steel in the concrete structure, up to a depth of $100 \mathrm{~mm}$, depending on the measurement range indicated to the equipment.

To determine the location and quantity of the reinforcing steel, the perimeter walls and center walls of the house were taken as a reference, each one was divided into 10 parts in its horizontal direction and 10 in the vertical direction, taking a total of 40 readings per housing, a standard measurement range was used, this division will help us to perform f ${ }^{\circ} \mathrm{c}$ measurements with the sclerometer. 
Galvanized Steel Multimalla Mesh $15 \times 20 \mathrm{~cm} \mathrm{Cal} 14$ was used for the construction of the houses, with an average covering of $14 \mathrm{~mm}$, the reinforcement details are shown in figure 2 .
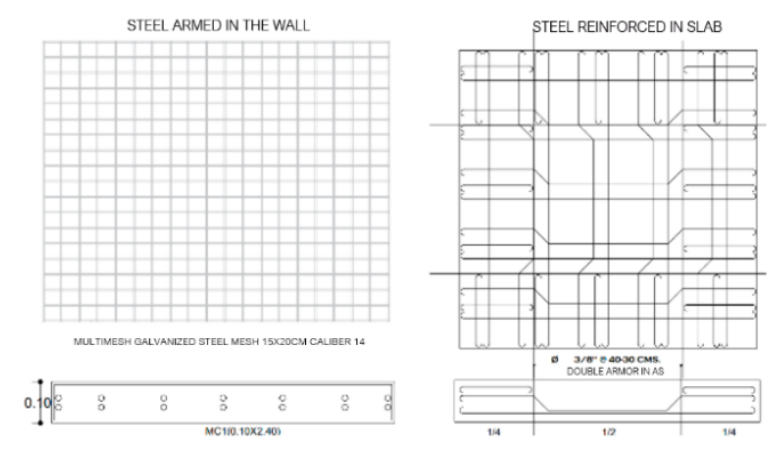

Figure 2 Detail of steel reinforcements

\section{Thermography}

The thermal imaging camera is a device that measures temperature and offers a thermal image of objects, without the need for contact, from their infrared radiation emissions. Objects emit an amount of infrared radiation based on their temperature.

For the measurement, a Fluke FLKTi400 9Hz Thermographic Camera model E554-1 was used, with which it was possible to exemplify the influence of emissivity on the surface temperature error, two thermograms were taken: the first with emissivity 0.9 (probable value very close to the real one) and with emissivity 0.1 (value very far from the real one).

The ceiling temperatures indicated by the camera when the emissivity is close to its real value, oscillate between 36 and $39 \mathrm{oC}$, (figure 3) unreasonable values for interior surface temperatures, it should be noted that, for qualitative applications, the use of a $u$ Another emissivity does not affect more than a change of scales to adjust the colors of the image, finding a lot of humidity in these adjoining all the walls.

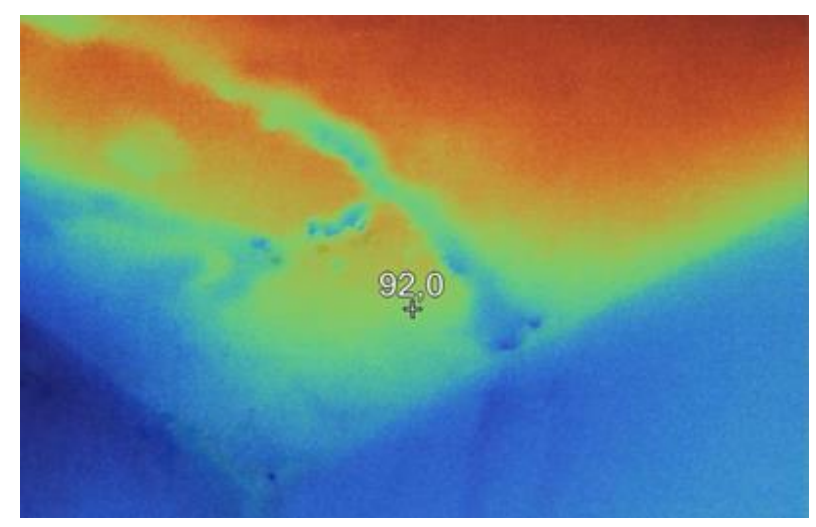

Figure 3 House bedroom thermography 2

The analysis of 5 dwellings was carried out at specific times of the day, one reading in the morning (9am), another in the afternoon $(3 \mathrm{pm})$ and another at night $(8 \mathrm{pm})$, in their different spaces and on their façade.

A great accumulation of heat was found, mainly in the slabs, due to the fact that they are made of concrete and are located at a very low height, in addition, a large amount of humidity is appreciated in the upper and lower part of the walls.

Moisture in reinforced concrete, usually occurs by capillarity, when the water rises from the ground through the material; or filtration, when water (usually rainwater) enters the interior of the building either by absorption, infiltration or penetration.

The results obtained can be seen in table 3.

\begin{tabular}{|l|r|r|r|}
\hline \multicolumn{4}{|c|}{ Temperature } \\
\hline - & Morning & Afternoon & \multicolumn{1}{l|}{ Night } \\
\hline House 1 & $29.6^{\circ} \mathrm{C}$ & $37.4^{\circ} \mathrm{C}$ & $34.3^{\circ} \mathrm{C}$ \\
\hline House 2 & $31.3^{\circ} \mathrm{C}$ & $37.8^{\circ} \mathrm{C}$ & $35.1^{\circ} \mathrm{C}$ \\
\hline House 3 & $29.9^{\circ} \mathrm{C}$ & $38.1^{\circ} \mathrm{C}$ & $33.7^{\circ} \mathrm{C}$ \\
\hline House 4 & $30.2^{\circ} \mathrm{C}$ & $37.2^{\circ} \mathrm{C}$ & $34.4^{\circ} \mathrm{C}$ \\
\hline House 5 & $30.8^{\circ} \mathrm{C}$ & $38.3^{\circ} \mathrm{C}$ & $35.4{ }^{\circ} \mathrm{C}$ \\
\hline $\bar{x}$ Temp. & $30.36^{\circ} \mathrm{C}$ & $37.76{ }^{\circ} \mathrm{C}$ & $34.58^{\circ} \mathrm{C}$ \\
\hline
\end{tabular}

Table 3 Thermography test results

\section{Soil mechanics}

The purpose of soil mechanics tests is to know the mechanical and physical properties of the soil, based on a series of samplings, as well as to identify and classify the material, determining its physical and mechanical properties. 
The results obtained in mechanics are relevant for the design and calculation of the foundation of the work, therefore there will be an immediate and necessary correlation between design-mechanics of soils.

Granulometry is a mechanical process by which the particles of a soil are separated in their different sizes, called the smaller fraction (Sieve No 200) such as silt, clay and colloid. A run is carried out using sieves in descending order. The results of the tests carried out are shown in Table 4.

For seismic design purposes, the Civil Works Design Manual of the Federal Electricity Commission in its Seismic Design section; establishes that the Mexican Republic is divided into four seismic zones, the study zone corresponding to the type $\mathrm{C}$ zone with a soil type 2 , having a coefficient of 0.64 .

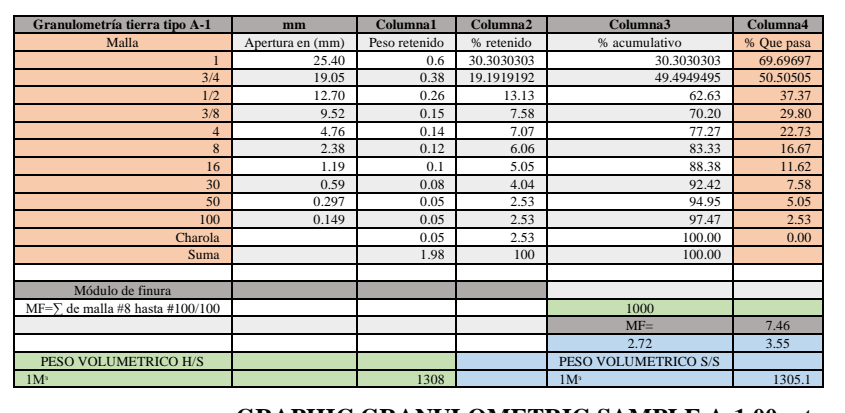

GRAPHIC GRANULOMETRIC SAMPLE A-1.00 mts

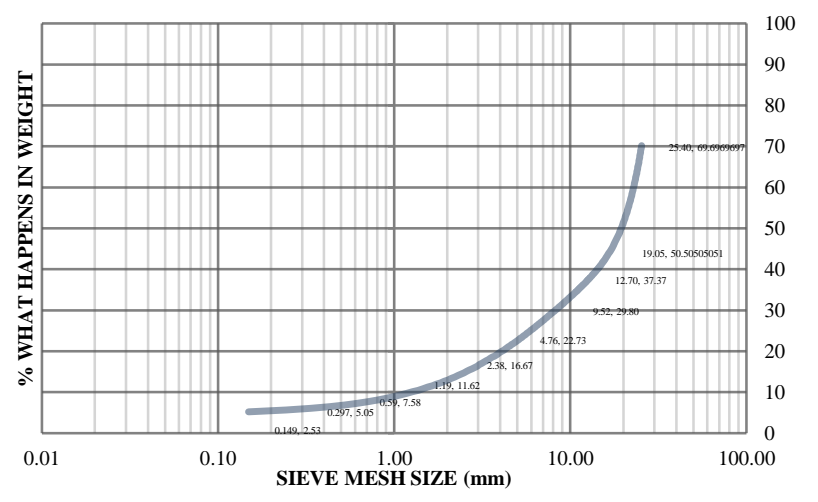

Table 4 Results of granulometric tests

The soil exploration was carried out by taking two samples: An altered open pit type to a depth of 1.0 meter, following what is indicated in the Mexican standard NMX-C431-ONNCCE-2002 "Sample Collection Altered and Unaltered".

In order to determine the stratigraphy of the soil on which the dwellings were placed, (Figure 4) and obtain representative samples of these strata and considering the type and consistency of the existing material, it was decided to carry out samplings using:

\section{Open Pit Wells (PCA).}

In the surveys, samples were taken of the soil material that was considered homogeneous in its characteristics throughout the area, the studies were used to determine the bearing capacity of the soil (qr), these samples will be tested for physical and granulometric characterization in order to classify them with the SUCS parameters according to the standard (ASTM D2487).

The results showed that the type of soil is defined as follows: Poorly graded sands, a mixture of silts and clays of low compressibility, which indicates that the soil has a $\mathrm{qr}=7.5 \mathrm{~kg} / \mathrm{cm}^{2}$.

Having said this, we can determine that the type of foundation used is not adequate and because of this the house can be affected by sand displacement or subsidence since clays of low compressibility are present.

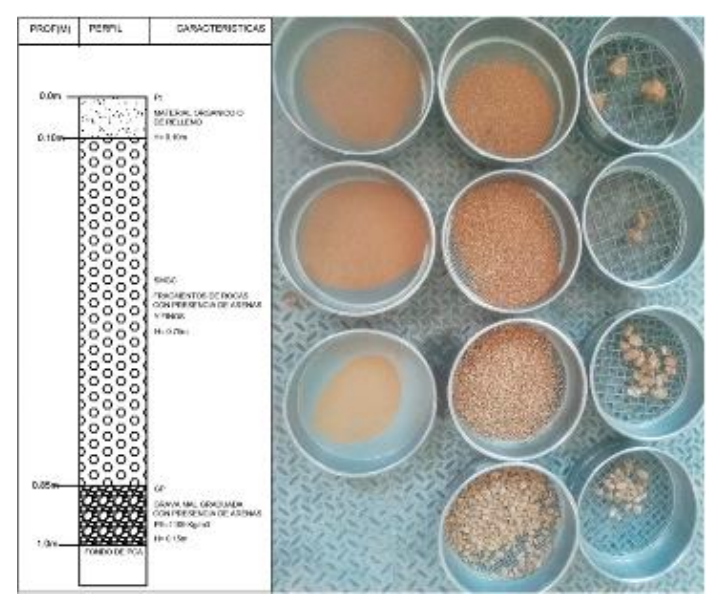

Figure 4 Stratigraphic profile and granulometry of the soil

\section{Architectural Proposal for housing rehabilitation}

After analyzing the houses and knowing the main problems they present, a better structure is proposed, which is expected to improve the comfort and comfort of the inhabitants and improve the view of the housing unit.

The problems to be solved are listed below.

HERNÁNDEZ-RODRÍGUEZ, Miguel Adrián, GÓMEZBARRANCO, Heidy and RODRÍGUEZ-SÁNCHEZ, Luz Cecilia. Architectural proposal for the rehabilitation and improvement of the houses of the city Yagúl housing unit, Oaxaca. Journal Architecture and Design. 2021 


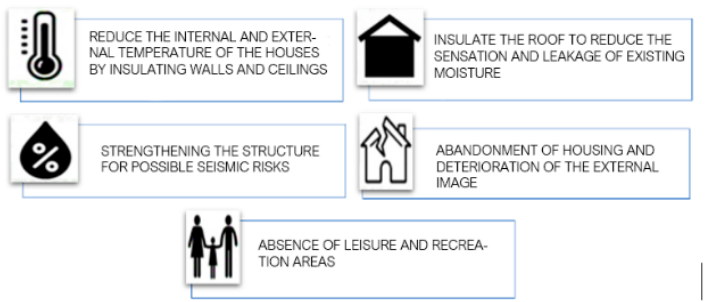

Figure 5 Problems to be solved in the housing unit

Two architectural solutions are proposed together, the first adding elements to the current home and the second expanding it. The plan of the current state of the houses is shown below.

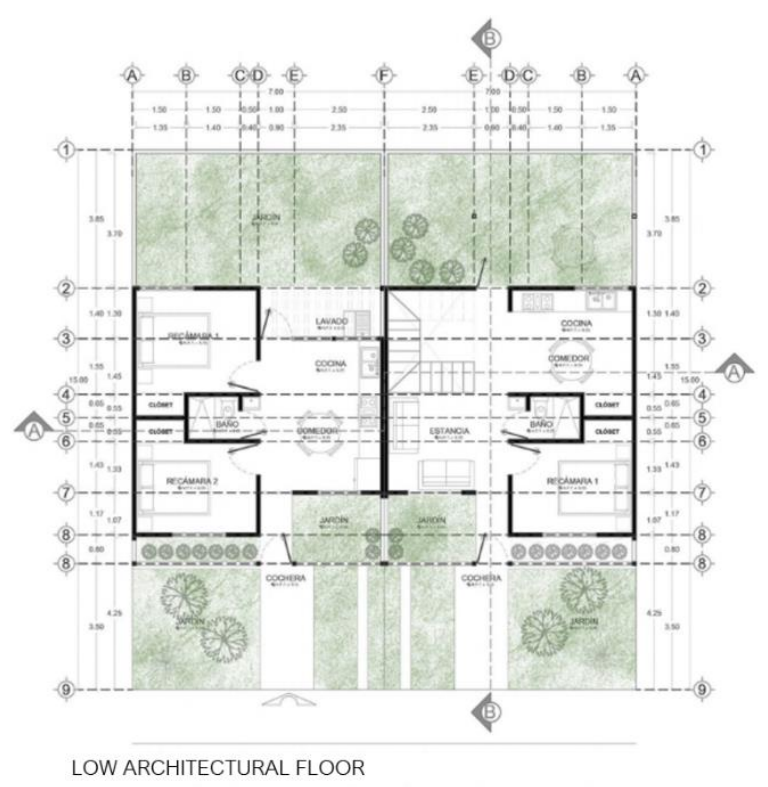

Figure 6 Current architectural plan

In this context, an architectural design with passive air conditioning is intended as a strategic approach. The objective is to manage the interior temperature of the houses without having to increase energy consumption to heat or cool them, avoiding the use of artificial systems such as air conditioning. It is important to improve the microclimate of the houses as much as possible, without the need for major or radical interventions.

The thermal improvement of houses with passive air conditioning and passive use of solar energy requires a complex optimization of all the construction elements in their interaction with the weather and use conditions; (Figure 7) passive design consists of understanding and directing well the heat fluxes in homes through design and proper management, to obtain the desired thermal comfort conditions.

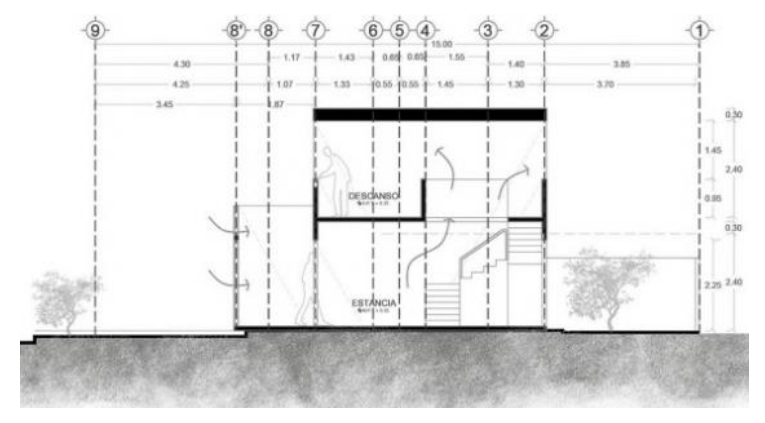

Figure 7 Air circulation diagram

The house in question has spaces that are too small, so an extension to a second floor is proposed, reorganizing the spaces: on the ground floor a guest bedroom, living room, kitchen and dining room, and on the upper part the addition of 2 bedrooms and a runner.

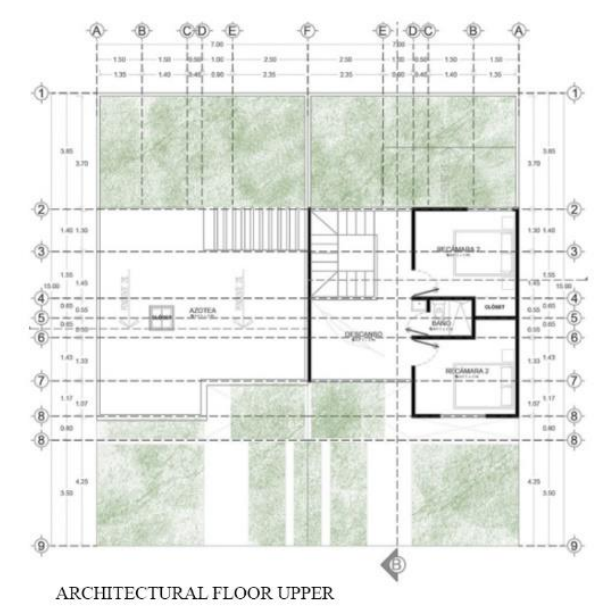

Figure 8 Proposal for the expansion of the upper floor

The scope of this passive air conditioning is to achieve:

- $\quad$ Superior thermal comfort.

- Minimal energy consumption for heating and cooling.

- $\quad$ Lower cost of energy and maintenance.

- $\quad$ Lower environmental impact.

In order to achieve these goals, some construction strategies are proposed in the houses.

\section{Cross ventilation}

Cross ventilation is based on generating natural air currents inside our home, that allow its renovation and at the same time improve the climatic conditions of the same. 
As can be seen in figure 9, a screen wall made of annealed clay lattices is proposed on the main façade, which in addition to functioning as an aesthetic element of the house prevents direct sunlight from entering and allows air circulation. Inside the house, the air passes through the lattice and then through a space with vegetation that helps to lower the temperature with which it will enter the house; This in order for the hot air to escape from the house and there is a constant air flow between indoors and outdoors.

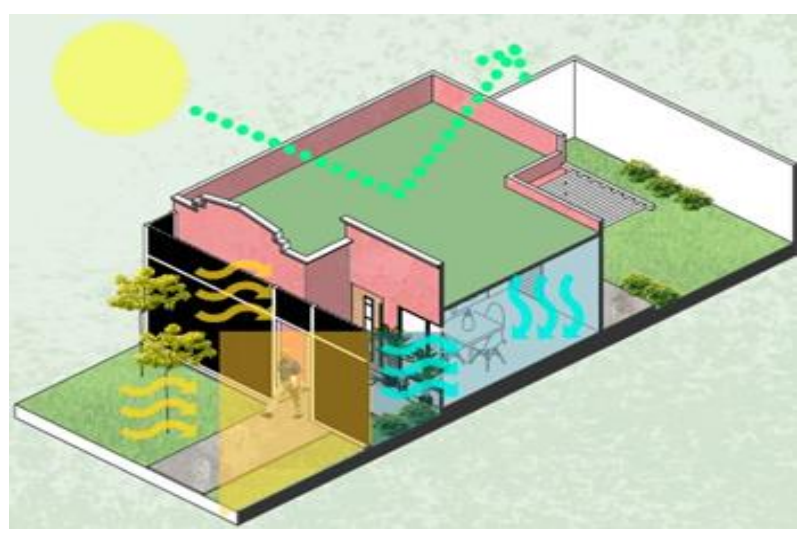

Figure 9 Climate diagram

\section{Blocking Solar Radiation}

For this, several sun protection systems are proposed:

Roof: fixed and horizontal system that allows shading the rear façade in summer, but allows solar radiation to pass through in winter. They are a very effective method to prevent our building from overheating in summer and can reduce the incidence of solar radiation by around $40 \%$.

Waterproofing: an important method to prevent water seepage, causing humidity in walls and ceilings. Given the high humidity content inside the houses, it is proposed to apply red or white waterproofing to the house that will prevent the humidity from continuing to expand through the different spaces, avoiding the appearance of fungi and mold.
- Green roof: it is an alternative that consists of placing a kind of garden on the roof of the houses. The green roof system shows to decrease the interior surface temperature, reduce oscillation and have better thermal performance than the reinforced concrete roof.

This advantage is attributed mainly to the low density and thermal conductivity values of the materials that make up the green roof and reduce the passage of heat through these components. Consequently, the ceiling provides less unnecessary heat to the user, placing it in adequate thermal states

Subsequent to the great problem of high temperatures, the adaptation of green roofs is proposed, which will maintain the interior with adequate thermal comfort for the inhabitants.

\begin{abstract}
Vegetation: In the front part of the houses, the planting of trees is proposed, this to create microclimates and shade that refresh the air that circulates and enters the house, apart from providing a better appearance to the facade and the housing complex in general., Species such as pochotes and acacias are proposed, this because they are not invasive and their maintenance is almost nil.
\end{abstract}

Inside the house a space with vegetation is proposed that helps to lower the temperature with which the air will enter the house, because the vegetation generates an effect called evapotranspiration that, basically, results in releasing moisture to the nearby environment, generating a greater feeling of freshness.

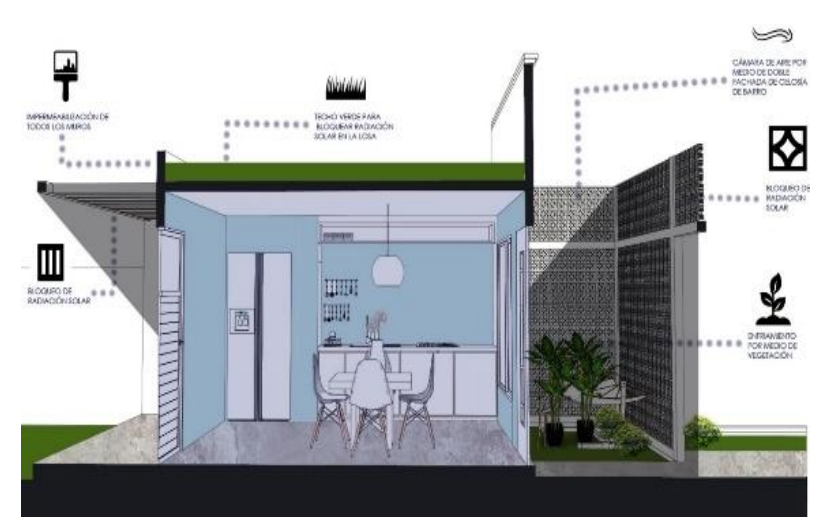

Figure 10 Housing design strategies 


\section{Structural reinforcement and expansion}

As can be seen in the non-destructive tests carried out on the houses, they are structurally weak, so a structural improvement based on confinement with castles and girders is proposed, which will give us structural security and support for the next improvement mentioned below.

The lack of space is one of the greatest adversities of the inhabitants, their small size does not allow them good mobility and not being able to have more furniture than the basic one, for this purpose, the expansion of the size of the houses is proposed, on the upper floor leaving more space for the dining room, living room and kitchen and moving the rooms upstairs.

As can be seen in Figure 11, an extension of the house with a second level is proposed, since adaptability is sought for a family of average size; also take advantage of the vertical circulation cube as a nucleus for natural lighting and cross ventilation.

Last but not least, it is intended to include water tanks for the storage of water, since the subdivision lacks planning of this supply and in times of droughts the inhabitants are affected

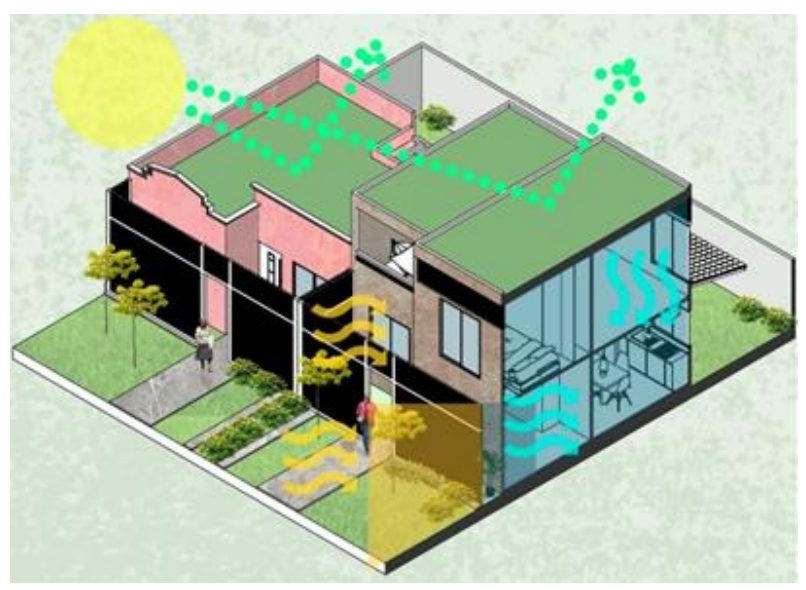

Figure 11 Housing expansion proposal

\section{Security and rescue of the subdivision}

As a local intervention and to solve the problem of insecurity that exists in the subdivision, it is proposed to place lights at every $50 \mathrm{~m}$ distance, in addition to the construction of 2 surveillance posts, in each of the 2 existing entrances.
For the rescue of the view of the fractionation, the planting of trees in the corners is proposed, species such as pochotes and acacias are proposed for planting, this because they are not invasive and their maintenance is almost nil, in addition, the creation of 2 recreation areas and social encounters, in abandoned land located in the north and south of the complex, thereby encouraging healthy recreation, coexistence and a sense of community (Figure 12).

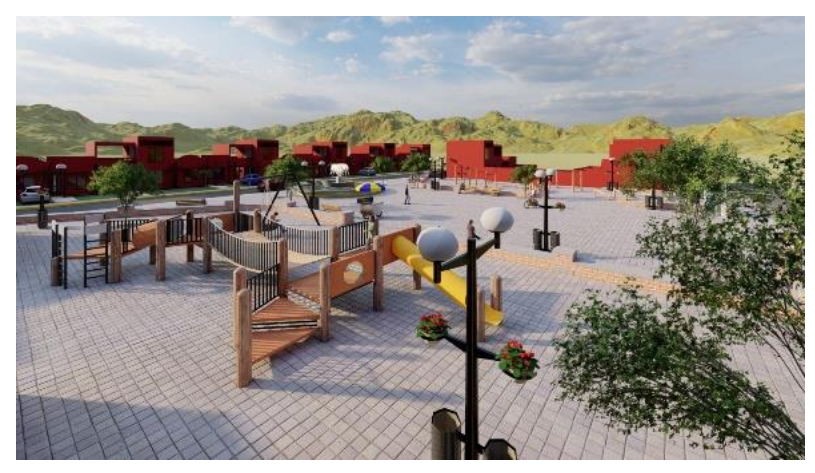

Figure 12 Proposal for a recreational area

\section{Results and conclusions}

After analyzing the homes of the Cd. Yagul housing unit through an analysis of the place and non-destructive tests, we can conclude:

The houses were not built complying with the established guidelines, the houses are in abandonment and in a progressive and accelerated deterioration due to the poor quality of the materials used.

Sclerometry tests indicate that the concrete's f'c fluctuated between 189 and 199 $\mathrm{kg} / \mathrm{cm}^{2}$; Therefore, these values are not acceptable for concrete according to the Construction and Structural Safety Regulations for the State of Oaxaca, which indicates a value of $\mathrm{f}^{\prime} \mathrm{c}$, equal to or greater than $200 \mathrm{~kg} / \mathrm{cm}^{2}$ for structural concrete.

The analysis of the quantity of steel, allowed to determine the variable or null presence of steel in the structure, using Galvanized Steel Multimalla 5x10 cm Cal 14. 
The Thermography analysis allowed to show the high temperatures inside the houses, their low height, as well as the concrete slab that they have give way to temperatures from 32 to $39{ }^{\circ} \mathrm{C}$ which makes it unbearable to stay inside them, according to the UNE-EN ISO 7730: 2006 standard, the ideal temperature for a house is 21 degrees Celsius.

With this test, the humidity within them was also evidenced, giving way to fungi and bad odors that put their inhabitants at risk.

With the proposal made and exposed above, it is possible to improve the thermal comfort of the houses, in addition to solving other problems such as the lack of water, expansion of spaces and bedrooms, the quality of life is improved, and the inhabitants can have a nice and worthy home to live in.

\section{Thanks}

The authors are grateful for the support of the Materials, Building and Environment Laboratory of the Faculty of Architecture "5 de Mayo" of the UABJO.

\section{References}

[I] Juan José Kochen (2017) "El ideal del multifamiliar: A 70 años del primer centro urbano moderno" Archdaily ISSN 07198914

[II] José Jesús Quivén (2016). Propuesta de Vivienda social sostenible para climas cálidos (tesis de maestría). Universidad Politécnica de Catalunya, España.

[III] NMX-C-431-ONNCCE-2002 "Toma de Muestra Alterada e Inalterada" Industria Mexicana de la Construcción.

[IV] NMX-C-083-ONNCCE-2014 "Determinación de la Resistencia a la Compresión en concretos" Industria de la Construcción.

[V] Cabrera \& Guillén, (2018). La problemática del abandono de la vivienda de interés social en las ciudades globales, una mirada desde sus habitantes (tesis de maestría). Facultad de Arquitectura de la Universidad Autónoma de Baja California
[VI] Coordinación Estatal de Protección Civil, (2003) Atlas de riesgo, tomo II. pp. 37.

[VII] Castillo-García, R. F. (2021). POLÍTICAS PÚBLICAS DE VIVIENDA EN EL PERÚ 1946-2021 Y APORTES PARA UNA POLÍTICA PÚBLICA DE VIVIENDA 2021-2030. Paideia XXI, 11(2).

[VIII] Secretaria de comunicaciones y transportes (2020). Métodos de muestreo y pruebas de materiales, capitulo 20 "Granulometría de los agregados pétreos" pp.3.

[IX] Comité Estatal de Planeación para el Desarrollo (2017). Plan Estratégico Sectorial Vivienda y Servicios Básicos. pp. 9-11.

[X] Casas, Luis Humberto (2012). Humedades. Programa Editorial UNIVALLE. pp. 42.

[XI] Juárez, B. y Rico, R.A. (2003). "Mecánica de Suelos". Tomo I. 3 Edición. Ed. Limusa. Pp.42.

[XII] Dr. Ing. Jorge Elías Alva Hurtado (1967). Diseño de Cimentaciones, 3ra Edición, Fondo Editorial ICG, pp. 46.62. 